\title{
Denver diversions
}

\section{Tours and activities at the 2001 ACRL National Conference city}

\author{
by Ellen Metter
}

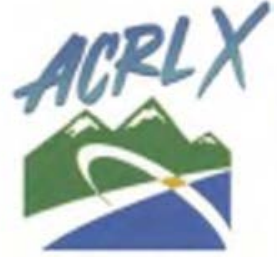

Going to a conference withour enjoying the local sights and cultural opportunities is like going for a Middle Eastern dinner and saying, "Hold the spices." The ACRL Local Arrangements Committee invites you to enjoy the remarkably varied offerings of Denver, the Mile High City, while you are in town for the March 15-18, 2001, ACRL National Conference.

\section{Tours for many tastes}

Tours have been created for those who want to meander in the mountains, as well as for those who like to rustle among the retail. Price and time details will appear in the conference program and on the Web site at www.ala.org/ $\mathrm{acrl} /$ denver.html).

\section{Denver historical tour}

Though Denver, founded in 1859 , is a relatively young city, it's managed to pile up a mountain of historic destinations. This tour begins at the Colorado State Capitol, modeled after the U.S. Capitol building. Topped by a 24-carat- gold-plated dome, the Capitol offers a fine view of Denver from the rotunda (get a virtual glimpse at http:// denvergov.org/panoramas/Rotunda.asp).

Step back in time when you visit the Gothic Victorian home of Molly Brown, renowned for her unsinkable ways and her life as a one of the nouveau riche in early Den-

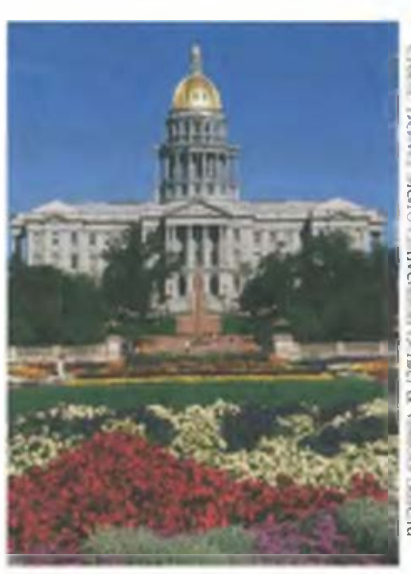

The dome of the Colorado State Capitol is covered with nearly 200 ounces of gold. ver society. Participants on this tour will also visit the famous Brown Palace Hotel. Triangularly shaped and clad in red sandstone, the hotel features a nine-story atrium and beautiful Victorian and Art Deco accents everywhere you look. High tea will be served featuring finger sandwiches, scones, petit fours, and, of course, special tea. The last stop on the tour is the U.S. Mint, one of only four mints in the United States.

\section{Colorado Springs scenic tour}

Scenic is an understatement when describing one of the destinations of this tour: the Garden of the Gods. Superlatives like "majestic" and "stunning" come to mind when describing this park's towering red rock formations. This tour also offers another gift of nature, the Cave of the Winds, born 200 million years ago-enough time to form a

\section{About the author}

Ellen Metter is professional studies bibliographer and reference librarian at Auraria Library, University of Colorado at Denver, e-mail: emetter@carbon.cudenveredu 
dramatic network of rooms encrusted with stalactites and stalagmites. This trip also stops at Colorado's most visited man-made attraction, the U.S. Air Force Academy. Wind up with a reception hosted by the library at the University of Colorado, Colorado Springs.

\section{Denver museum tour}

This tour features three of Denver's bestknown and -loved museums. The Colorado History Museum presents exhibits on the areas earliest inhabitants, the Native Americans, as well as the state's earliest settlers. During the convention you'll see an exhibit spotlighting Bill Cody titled Buffalo Bill's Wild West.

The Denver Museum of Nature and Science delves into the discoveries of man and the intricacies of the natural world. During your visit, the museum will be featuring the exhibit Vikings: The North Atlantic Saga, a special exhibition developed by the Smithsonian. The Denver Art Museum, noticed by passersby for its fortress-like appearance, houses a wide variety of art genres and will be featuring a special exhibit of works by Winslow Homer during the ACRL National Conference.

\section{Shop 'til you drop tours}

Two arranged shopping tours will be available: one around and about Denver and one in the foothills of Boulder. Upscale shopping is the offering at Denver's Cherry Creek Mall, with such anchor stores as Saks Fifth Avenue and Neiman Marcus. Shops unique to Colorado are a block north of the

\section{Local transportation}

Taxi services (Taxis must be called; they are not easily flagged down from the street.)

- American Cab: (303) 321-5555

- Metro Tax: (303) 333-3333

- Yellow Cab: (303) 777-7777

- Zone Cab: (303) 444-8888

All calss offer 24-hour service.

Bus schedules and light rail information

Regional Transportation District (RTD), (303) 299-6000; outside (303) area code: (800) 366-7433; homepage: http:/ www.rtd-denver.com/. mall, in North Cherry Creek. Walk from boutique to gallery in this delightful area, with plenty of chances to warm up with coffee or lunch.

The influential Tattered Cover Book Store is also in North Cherry Creek. Check their homepage (http://www tatteredcover.com/) to see which writers will be speaking the week of the conference-authors appear nearly every day at either the Cherry Creek or LoDo store.

This tour will also bring you to the Park Meadows Retail Resort, home to Nordstrom's, Dillard's, and a high-quality food court.

The first stop on the Boulder shopping day will be Flatirons Crossing, the newest mall in the Denver area. Travelers will then enjoy the breathtaking view rewarded to those who travel into Boulder - the Flatiron Mountains. Boulder's Pearl Street Mall is a collection of locally owned boutiques, nationally known stores, galleries, and nearly 100 eateries on an outdoor mall closed to traffic. It's nestled in the lovely Colorado foothills, making a stroll down the mall a relaxing and picturesque experience. Do visit one of the town's most popular independent bookstores on the mall, the Boulder Bookstore.

\section{Library tour}

See how the marriage of a public library and a college library in one building can be a beautiful thing-the College Hill Library at Front Range Community College in Westminster. Visitors will then travel to Boulder to see the Earth Science Library on the beautiful campus of the University of Colorado, Boulder. The trip to Boulder also includes a lunch at NetLibrary followed by a tour of this innovative company.

\section{LoDo (Lower Downtown) tour}

The ACRL National Conference is located in Denver's Lower Downtown (LoDo), an area that used to be avoided by anyone who wanted to feel safe. No more. Now this area brims with businesses, lofts, restaurants, nightlife, and shopping. For this tour, participants ride a motorcoach through LoDo, hearing tales of the graciously appointed Oxford Hotel, the oldest in Denver, and the historic, high-ceilinged Union Station, home of the ski train and a store featuring train collectibles. 
This trip also features an in-depth tour of Coors Field, where the Rockies' faithful gather and the ball goes amazing distances in Denver's mile-high atmosphere. Lunch will be at the popular Wynkoop Brewing Company, Denver's first brewpub, featuring such pub fare as shepherd's pie and beer-braised pot roast- not to mention about a dozen beers brewed on the premises. The LoDo Tattered Cover Bookstore, sister to the original in Cherry Creek, is the last stop on the tour, offering a coffee bar and plenty of warm, comfortable places to linger and book browse.

\section{Taste of the Rockies}

This tour offers tasty tidbits for your eyes and mind. It begins with a visit to the gorgeous Red Rocks Amphitheater, an outdoor concert area built among soaring red sandstone formations. Then learn of that renowned figure of the West, Buffalo Bill Cody, when you see his gravesite and museum atop Lookout Mountain. This tour builds a thirst, so it ends with a walking tour through Coors Brewery in Golden, Colorado-with samples most definitely available.

\section{Mountain getaway}

The mountains are clearly seen from Denver, but to truly experience their wonder, you need to be surrounded by them. The Local Arrangements Committee is working to arrange passage for ACRL members to local peaks; stay tuned for more announcements on this opportunity.

\section{Touring on your own}

Interesting destinations abound in Denver and its surrounding towns. When relying on mass transit, be aware that Denver's taxi service is more cowtown than big city; you need to call taxis, they're not roaming around. Plan ahead. Since the conference is on St. Patrick's Day weekend, there may be more than a few sensible people choosing taxi service. (See the sidebars for taxi and bus information and for local attraction hours and contact information.)

\section{Denver March Pow- wow}

ACRL members are fortunate to be visiting Denver while the acclaimed Denver March Powwow is being held, March 16-18, 2001, from Friday through Sunday. Many make a point of traveling to Denver just for the Powwow! Native Americans dance, sing, and drum in colorful full regalia at this event. The Powwow also features a market offering Native American arts, crafts, and jewelry.

\section{Western history}

In addition to the marvelous destinations included in the Denver Historical Tour described above, there are more options for those curious about the history of the West. Did all cowboys look like John Wayne? Not quite. Nearly a third of the cowboys of the early West were black. Visit the Black American West Museum \& Heritage Center to learn more about black cowboys, homesteaders, ranchers, and frontier professionals.

In years gone by, more than 2,000 miles of narrow gauge railroad tracks were actively traveled in the Colorado mountains. Take a 12-mile trip west of Denver to the Colorado Railroad Museum to view historic records, mementos, artifacts, and photographs of Colorado's railroads.

\section{For the kids}

If the offspring are along, consider visiting the Children's Museum of Denver. The museum focuses on children aged newborn through eight and offers interactive exhibits and plenty of hands-on learning experiences.

\section{For the latest information}

Watch the ACRL Conference Web site for more information and registration forms at www.ala.org/acrl/denver.html 
Both children and adults will also enjoy the impressive new aquarium Colorado's Ocean Journey, featuring 15,000 marine creatures and a few Sumatran tigers to boot.

\section{Traipsing about: Shopping, sightseeing, and wandering}

You need only your feet to peruse most of downtown Denver. If you're in the mood for some crane-your-neck architecture, stroll down 17th Street-it's chock full of skyscrapers and is known as the "Wall Street of the West."

A beautiful architectural sight in the evening is Denver's Gas and Electric Building (at 15th and Champa Streets), which was built in 1910 and is illuminated by thousands of lights that trace the details of the building's exterior decorations

For a leisurely stroll with the city out of sight and the sound of rushing water at hand, pop down to the Cherry Creek Path, a favorite of bicyclists, joggers, roller blaclers, and pedestrians, winding along the banks of Cherry Creek. The path has a downtown entryway on Larimer Street between 14th Street and Speer Boulevard.

Just three blocks from the Convention Center is Larimer Square (Larimer Street between 14 th and 15 th Streets), a charming LoDo area featuring restored turn-of-the-cen-

\section{Attraction hours and contact information}

\section{Black American West Museum \& Heri-} tage Center, 3091 California Street, Denver, (303) 292-2566, http://www.coax.net/ people/lwf/bawmus.htm. Open Wednesday-Friday, 10 a.m.-2 p.m.; Saturday and Sunday, $12-5$ p.m.; and closed Monday and Tuesday.

Cherry Creek Shopping Area, by car, take Speer Boulevard South. The mall is just past University Boulevard on Speer. By bus: Take the \#2 from the stop across from the Market Street Station. Check the RTD homepage at http://www.rtd-clenver.com/ for details.

Children's Museum of Denver, 21,21 Children's Museum Drive, I-25 and 23rd Avenue (Exit \#211), (303) 433-7444, http:// www.cmdenver.org. Open Tuesday-Sunday, 10 a.m. -5 p.m.

Colorado History Museum, 1300 Broadway, Denver, (303) 866-3682, http:// www. coloradohistory org/colorado history_museum/. Open Monday-Saturday, 10 a.m. $-4: 30$ p.m.; and Sunday, 12-4:30 p.m.

Colorado Railroad Museum, 17155 W. 44 th Street, Golden, Colorado. By car take I70 west to exit 256 and follow the signs, (303) 279-4591 or (800) 365-6263, htıp://www.crrm.org/. Open every day, 9 a.m. -5 p.m.

Colorado State Capitol, Broadway and Colfax, Denver, (303) 866-2604. Tours are Monday-Friday, every 45 minutes, starting at 9 a.m., the last tour is at 2:30 p.m.

\section{Coors Field-Home of Colorado} Rockies Baseball, (303) 312-2108, http:// wow rockies.com/. In March there are at least four tours a day, but times may vary. Call for exact times.

Denver Art Museum, 100 W. 14th Avenue Parkway, Denver, (303) 640-4433, http://www.denverartmuseum,org/. Open Tuesday and Thursday-Saturday, 10 a.m.5 p.m.; Wednesdays, 10 a.m.-9 p.m.; and Sundays, $12-5$ p.m.

Denver Museum of Nature and Science, 2001 Colorado Blvd., Denver, (800) 925-2250 or (303) 322-7009, http:// www.dmnh.org/. Open daily from 9 a.m5 p.m.

Denver Powwow, Denver Coliseum, (303) 934-8045, http://www.denvermarchpowwow. org/. By car: I-25 to I-70, take the Brighton Blvd. Exit. By bus: Take the $\# 48$ from 16 th and Curtis Streets. Check the RTD homepage for more details. March 16-18, 2001.

Molly Brown House Museum, 1340 Pennsylvania St., Denver, (303) 832-4092. Open Tuesday-Saturday, 10 a.m. -4 p.m.; Sundays, $12-4$ p.m.

Colorado's Ocean Journey, U.S. West Park, 700 Water Street, Denver, (303) 5614450 or (888) 561-4450, http://www. oceanjourney.org. Open daily 10 a.m.-6 p.m.

U.S. Mint, West Colfax at Cherokee St., (303) 844-3582. Open Monday-Friday, 8 a.m. -3 p.m. 
tury buildings, dining, stores unique to Colorado (like Earthworks, featuring items crafted by Coloradans), as well as popular retail stores. Just beyond Larimer Square, Writer's Square is a pretty retail and gallery area on Larimer Street between 15 th and 16 th.

Theater and movie aficionados will want to visit Scene to Screen, "Denver's Largest Theatrical Book Store." Located on 14th Street, between Curtis and Arapahoe, Scene to Screen sells books, scripts, posters, sheet music, and other stage- and film-related gewgaws.

Shopping opportunities continue downtown on the 16th Street Mall, a 12-block pedestrian mall, free from cars but offering continuously running no-cost buses shuttling visitors from one end to the other from Market Street to Broadway, with stops at every cross street. There is one enclosed mall on 16th Street, the Tabor Center, between Larimer and Arapahoe, and one semi-covered mall, the Denver Pavilions, featuring such stores as Barnes and Noble and Virgin Megastore.

If you can't make a Coors Field tour, you can still enjoy the plaza to the west of the stadium. Take the pathway leading to the sta- dium at Wynkoop and 19th Street. You'll pass great eateries (the Denver Chophouse and Brewery, Sing Sing, and Fadó's Irish Pub) and see. laid in the shape of a ballfield and surrounded by the lyrics of "Take Me Out to the Ball Game," hundreds of bricks donated and inscribed by ballpark supporters. Nearby, take a close look at the hilarious arched sculpture titled "Evolution of the Ball" (Lonnie Hanzon, 1995) featuring sculpted and enhanced renditions of all sorts of balls, including a skee ball, eye ball, red rubber ball, goof ball, and, but of course, Lucille Ball.

\section{Check the temp}

March weather in Denver is, in a word, unpredictable, so check the forecast before arriving. Though March temperatures are typically in the 50 s with lots of Colorado sunshine, we've been known to produce a surprise heat wave or snowfall.

So, what about nightlife in the Queen City of the Plains? There's plenty-great eating, dancing, music, comedy, sports, and theater. Look for details on Denver nighttime fun in the January issue of $C E R L$ New's, and descriptions of eateries in the February issue.

\title{
会 $\Delta$ \\ American Theological Library Association
}

\section{The American Theological Library Association}

\section{has moved}

our new address is

\section{South Wacker Drive, Suite 1600 Chicago, Illinois 60606-5834}

\author{
Toll free: $888-665-2852$ \\ Outside North America: $\quad 312-454-5100$ \\ Fax: $312-454-5505$ \\ E-mail: atla@atla.com \\ Web site: http://www.atla.com
}

In honor of the occasion, ATLA cordially invites all our members and friends to celebrate at our Open House, Friday, November 3, 2000, from 2:00 to 4:00 p.m. Please RSVP by calling Theresa Mendoza, ATLA Office Manager. 


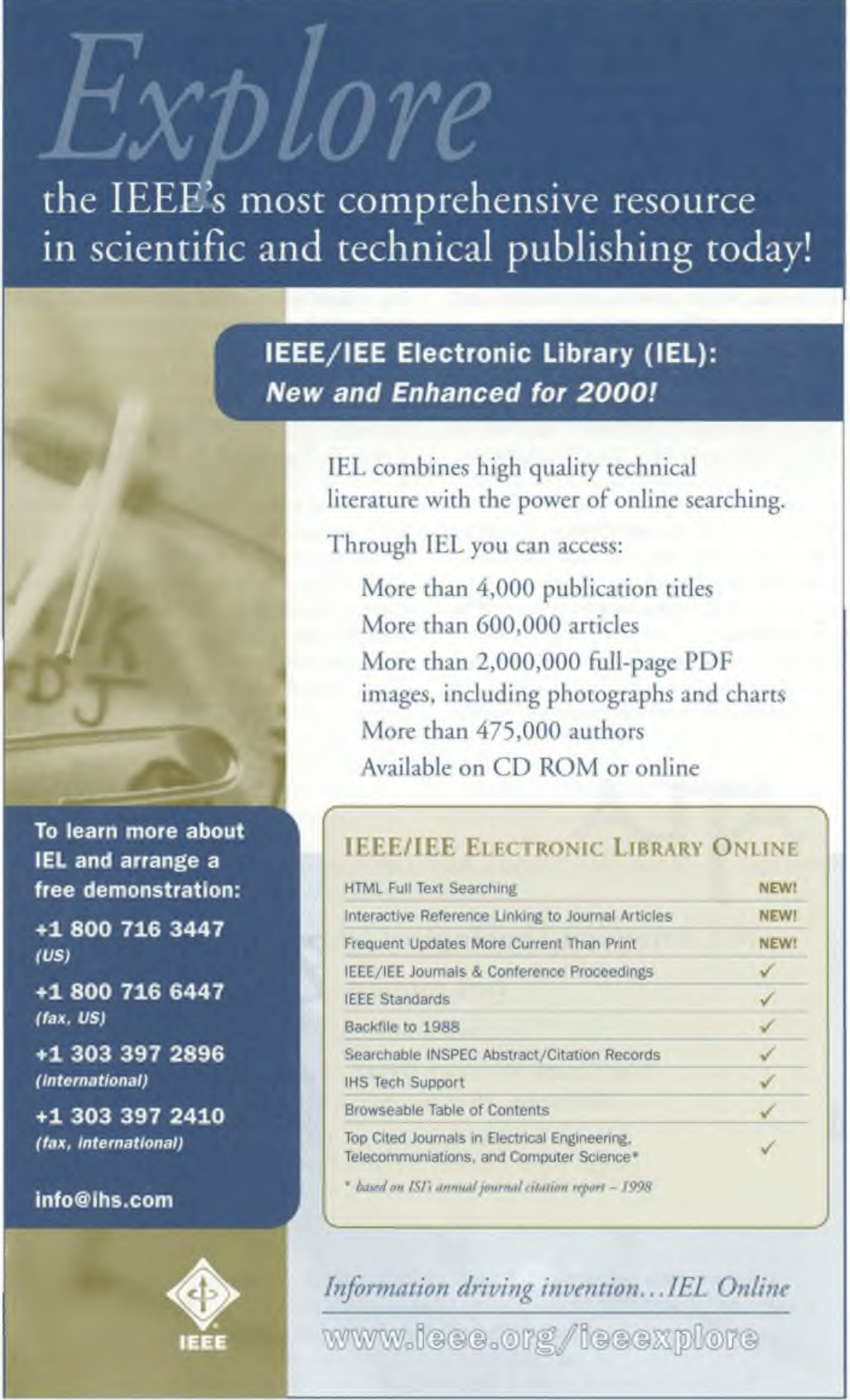

